\title{
The Census of the Russian Empire
}

Author(s): P. K.

Source: The Geographical Journal, Vol. 9, No. 6 (Jun., 1897), pp. 657-659

Published by: geographicalj

Stable URL: http://www.jstor.org/stable/1774927

Accessed: 26-06-2016 18:36 UTC

\section{Your use of the JSTOR archive indicates your acceptance of the Terms \& Conditions of Use, available at}

http://about.jstor.org/terms

JSTOR is a not-for-profit service that helps scholars, researchers, and students discover, use, and build upon a wide range of content in a trusted digital archive. We use information technology and tools to increase productivity and facilitate new forms of scholarship. For more information about JSTOR, please contact support@jstor.org.

The Royal Geographical Society (with the Institute of British Geographers), Wiley are collaborating with JSTOR to digitize, preserve and extend access to The Geographical Journal 
In Tasmania, a survey was made of Wedge bay and the adjacent coast of the Tasman peninsula from Frederick Henry bay to Port Arthur on a scale of 2 inches to the mile; and a triangulation completed of the south-east extremity of the Tasman peninsula.

On the coast of Queensland, the survey of the inner route has been continued and completed between Restoration island in lat. $12^{\circ} 37^{\prime} \mathrm{S}$. and Binstead island in lat. $13^{\circ} 13^{\prime} \mathrm{S}$. The Pearn reef, which has on several previous occasions been unsuccessfully searched for, having been originally reported by a small pearling schooner, was found. It consists of a small coral rock with only 10 feet of water over it, and as it lies almost exactly on the track of vessels using the inner route, its discovery will probably avert a disaster. Sectional lines of soundings outside the reef were obtained at the Grafton and Palm passages.

In the islands of the South-West Pacific, Funafuti island in the Ellice group was surveyed on a scale of 2 inches to the sea mile, and the anchorage on 6 inches. At this island, Professor Sollas, F.R.s., and a party were landed to conduct boring operations, which it was hoped would aid in elucidating the structure of coral atolls. These operations were carried out at two positions to depths of 100 and 70 feet respectively, when in each case they bad to be abandoned owing to the presence of quicksand and boulders, which prevented further advance without special gear. Sectional lines of soundings were run out from the reef at several places round the atoll to determine its outer slope.

At Nukulailai islaud, also one of the Ellice group, a sketch-survey was made, and a sketch-plan of the anchorage.

The island of Rotumah and neighbouring islets was surveyed, and a plan of the anchorage made.

The north coast of Viti Levu, Fiji, with its extensive tract of off-lying reef, was surveyed between Nakorokoro point and Mathuata island.

In the course of voyages and of searches for reported reefs, a large number of leep-sea soundings have been obtained in the Suuth-West Pacific. Various banks were disproved, while others were verified and sounded, and a new bank was found. Magnetic observations have been obtained at Funafuti (Ellice group), Levuka (Fiji), and at Cairns (on the Queensland coast).

In India, work was commenced on the Sind coast, and coast-line and soundings for 20 miles off shore completed between Kori and Godia creeks.

The eastern part of Bombay harbour was surveyed on a scale of 2 inches to the sea mile, and large-scale plans of the approach to the Government docks.

The north-east end of North Andaman island was surveyed on a 1-inch, and Port Cornwallis on a 3-inch, scale.

During the year the Hydrographic Department has published 87 new charts and plans, and 20 plates bave been improved by the addition of 25 new plans, while 4331 corrections have been made to the chart plates. The number of charts printed for the requirements of the royal navy, for Government departments, and to meet the demand of the general public has amounted to 344,118 .

\section{THE CENSUS OF THE RUSSIAN EMPIRE.}

'THE first general census in the Russian Empire, which was taken on February 9, 1897, is completed, and the collected materials are now verified on the spot, while a considerable portion of them has already been transmitted to the central Statistical Committee. The chief Census Committee has asked, in the mean time, all local 
census committees to communicate to St. Petersourg the details of their results, which was done, partly by telegraph, for all provinces, with the exception of parts of the province Yakutsk, for which the returns had to be supplemented by estimates. The general items are now published in the Official Messenger (May 16, 1897) in the shape of two tables. The first table contains the population, according to the new census (males and females separately), for each of the eighty-nine governments and provinces of the empire, the superficies of the same, the density of population per square verst, and the percentage of females, as well as the total items for each province according to the ninth census of 1851 , and the subsequent estimates of the central Statistical Committee for 1858 and 1885. The second table gives a list of the capitals of each province, and all towns having a population over 25,000.

Previous censuses, the last of which took place in 1851 and 1858, were made, for fiscal purposes, by the police, which gave the permanent residents and tax-payers at each spot. This was, on the contrary, a one-day census-the first made in all the Empire-in which every person which was in a given spot on February 9 (about that date in the villages) had to be mentioned in the house to house lists for that spot, whether permanently residing in it or not.

The general items appear as follows :-

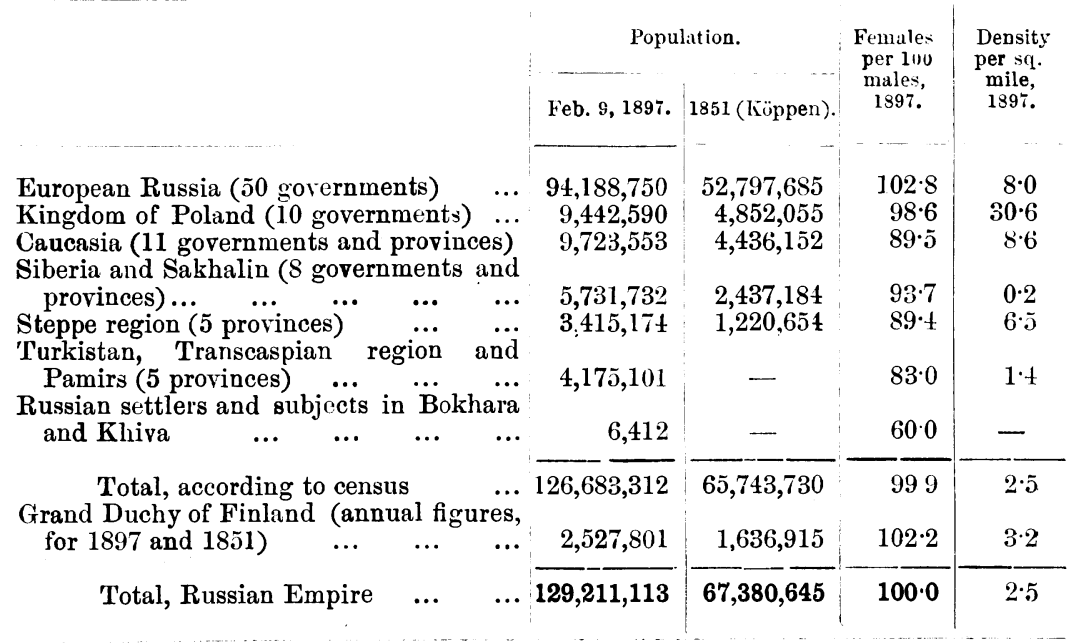

It would thus seem that the population has nearly doubled within the last fifty years.

As to the density of population, it is highest in Poland (47.4 per square mile in Piotrkóv); next come South-West Russia (29.7 in Podolia, $28 \cdot 8$ in Kieff) and Southern Russia (23.1 in Poltava); while in Middle Russia the density is about eighteen per square mile, and of course very much more in separate districts.

The population of towns has rapidly increased lately, there being now nineteen towns which have more than 100,000 inhabitants : namely, St. Petersburg, 1,267,023 (with suburbs); Moscow, 988,610; Warsaw, 614,752; Odessa, 404,651 ; Lódz in Poland, 314,780 ; Riga, 282,943 ; Kieff, 248,750; Kharkoff, 170,682 ; 'Tiflis, 159,862 ; Wilna, 159,568; Tashkent, 156,506 ; Saratov, 133,116 ; Kazan, 131,508 ; Ekaterinoslav, 121,216 ; Rostoff-on-Don, 119,889 (149,201 with Nakhichevan); Astrakhan, 113,075; Baku, 112,253; Tula, 111,048; and Kishineff, 108,506. There are besides thirty-five towns having a population of over 50,000 inhabitants, and sixty-nine more towns whose population is in excess of 25,000 . 
It is, of course, very interesting to compare the previous estimates with the present definite data. Having carefully compiled, during the last ten years, for the 'Statesman's Year-book, all isolated data concerning population that were published by the local statistical committees, relative to different years, and having calculated from these figures the estimated population, according to the probable increase, I arrived at the following figures for the end of 1895 : European Russia, 95,750,000 ; Poland, 9,220,000 ; Caucasus, 8,600,000; Central Asia, 6,375,000; Siberia, 5,140,000 ; Finland, 2,460,000 ; total, Russian Empire, 129,545,000 ('Statesman's Year-book,' 1897). These figures were, as might have been expected, and is now seen, in default for Caucasia and Turkistan, as also for Siberia, and in excess for European Russia, the total differing from the census figures by about one per cent. only.

The census was organized and carried on by a special committee, under M.P.P. Semenoff, who was, in 1869, the organizer of the first one-day census in Russianamely, at St. Petersburg-and has since developed the system in all details. A considerable number of men, many of whom were volunteers, took part in this immense work. Notwithstanding the considerable obstacles offered by the immensity of the territory and the difficulties of communication with the villages, the census was a decided success. There were, of course, some regretful incidents, due to the hostility of the population to all censuses, which are considered as preliminary to new taxes.

P. K.

\section{THE MONTHLY RECORD.} EUROPE.

The Gradual Extinction of the European Bison.-In the second number of volume iii. of the 'Memoirs of the St. Petersburg Academy of Sciences' (8th Series -Physical Mathematical Class), Eugene Büchner discusses the question of the gradua! dying out of the Bison borassus in the forest of Bielowyesha (Lithuania), adducing statistics to show that such a process is really going on, and investigating the causes to which it may be ascribed. He gives tables showing the approximate numbers of the bisons for each year from 1832 to 1892, from which it may be seen that, whereas from the former year to about 1855 the numbers were increasing, reaching a maximum of 1898 head in 1857, from that date onwards a diminution has on the whole been observed. The lowest figure (380) is given for the year 188y, but, as the writer shows that implicit reliance cannot be placed on the figures, the apparent slight increase since that year cannot be taken to show that a real improvement has set in. Herr Büchner discusses in turn the damage effected by various causes, such as the intentional killing of the bisons, either by authorized or unauthorized persons; the despatch of specimens to various zoological gardens; the destruction by wild beasts, especially bears and wolves; the disturbance caused by the two Polish insurrections; the diminution in the area of the pasture grounds, and so forth. But, while allowing that many of these have operated in the pastthe effects of the big "drives" set on foot for the capture of living specimens being especially detrimental-he considers that, with the increased care exercised in recent years for the preservation of the species, none of these causes are sufficient to account for the gradual progress towards extinction which is undoubtedly going on. $\mathrm{He}$ looks rather to the increasing unproductiveness of the bisons themselves as the cause, and, dismissing various theories by which it has been sought to account for this characterist: c, considers that it is due to the continued in-breeding which has of necessity been maintained. The same cause, he thinks, may account for the disappearance of the great post-tertiary mammals, which has never been satisfactorily explained, so that the study of the present condition of the Lithuanian bison may 